\title{
Genetic differentiation, reproductive mode, and gene flow in the brooding coral Pocillopora damicornis along the Great Barrier Reef, Australia
}

\author{
David J. Ayre ${ }^{1, *}$, Terence P. Hughes ${ }^{2}$, Rachel J. Standish ${ }^{1}$ \\ ${ }^{1}$ Department of Biological Sciences, University of Wollongong, Wollongong, New South Wales 2522, Australia \\ ${ }^{2}$ Department of Marine Biology, James Cook University of North Queensland, Townsville, Queensland 4811, Australia
}

\begin{abstract}
The widespread and morphologically variable coral Pocillopora damicornis has been reported to exhibit huge variation in life-history traits (e.g. mode of reproduction, growth rate, longevity and dispersal) both locally and regionally throughout the Indo-Pacific Ocean. Dispersal may be achieved by the settlement of sexually or asexually generated brooded planula larvae, by broadcast spawning or more locally through asexual fragmentation of large colonies. In the present study, we conducted a hierarchical survey of allozyme variation within and among reef-crest sites on 3 mid-shelf reefs separated by up to $1200 \mathrm{~km}$ on the Great Barrier Reef (GBR), Australia. Our objective was to use allozyme data (1) to quantify local and regional patterns of variation in $P$. damicornis (along the northeastern coast of Australia)، (2) to determine the relative contribution of sexual versus asexual production of planulae in $P$. damicornis, and (3) to estimate levels of gene flow among adjacent sites $(>5 \mathrm{~km}$ apart) and among reefs separated by 500 to $1200 \mathrm{~km}$. High levels of genotypic diversity in our samples of $P$. damicornis imply that dispersive propagules in this species are produced sexually rather than asexually along the length of the GBR. Corals at all sites displayed the same level of multi-locus genotypic diversity expected for randomly mating, sexually derived populations, and the majority of individual colonies possessed unique 7-locus genotypes. We also detected consistent deficits of heterozygotes within each collection (from 3 local sites on each of the 3 widely spaced reefs). This pattern is consistent with the predicted effects of sexual reproduction associated with some localised dispersal of gametes or larvae (although other explanations cannot be excluded). Furthermore, each reef was genetically subdivided, suggesting that larval recruitment was localised and that these populations are slightly inbred: hierarchical analysis of the standardised genetic variances $\left(F_{\text {ST }}\right)$ (estimated as Weir \& Cockerham's $\theta)$ revealed that, although there was only moderate variation among all 9 sites $\left(F_{\mathrm{ST}}=0.055\right.$ $\pm 0.029)$, more variation was found among sites within reefs $\left(F_{\mathrm{SL}}=0.035 \pm 0.04\right.$ to $\left.0.088 \pm 0.033\right)$ than among distant reefs $\left(F_{\mathrm{LT}}=0.008 \pm 0.014\right)$. This homogeneity of gene frequencies across widely separated reefs implies that reefs are connected by high levels of gene flow $\left(N_{\mathrm{e}} m \approx 31\right)$ and that local populations of $P$. damicorn s separated by $>1000 \mathrm{~km}$ can interbreed sufficiently to maintain a consistent suite of life-history characters.
\end{abstract}

KEY WORDS: Gene flow - Corals - Life history Population genetics Recruitment Sex Asexual reproduction

\section{INTRODUCTION}

Detailed studies of a range of freshwater and terrestrial taxa have demonstrated substantial spatial variation in life-history traits, including the mode of repro-

•E-mail:d.ayre@uow.edu.au duction (e.g Innes \& Hebert 1988, Hebert et al. 1988, Holtsford \& Ellstrand 1992, Ayre et al. 1994) and the dispersive capability of propagules (Wilson \& Herbert 1992). These characters may be genetically determined and strongly subject to natural selection (Stearns 1989, Carvalho 1994). In addition, large- and meso-scale geographic variation in the expression of 
life-history characters can result from phenotypic plasticity and from selective responses to environmental variation or gradients (review by Stearns 1989). Much less is known about spatial variation in life histories of marine organisms, which are rarely examined throughout their geographic range (but see for example Mackay \& Doyle 1978, Ayre \& Willis 1988, Toonen 1993).

Population genetics offers a powerful approach for estimating the relative contributions of differing modes of reproduction, and for quantifying the level and spatial extent of gene flow (e.g. Stoddart 1983, Johnson \& Black 1984, Ayre 1990). At one extreme, many marine taxa generate planktonically dispersed, genotypically diverse colonists that are generated by outcrossed sexual reproduction (Thorson 1950, Hedgecock 1986). These species can form vast, panmictic populations that are strongly interconnected by gene flow. They display a good fit to the expectations of the HardyWeinberg equilibria, are relatively diverse genotypically, and show little genetic subdivision (e.g. Hunt \& Ayre 1989, Williams \& Benzie 1993, Murray-Jones \& Ayre 1997). Alternatively, other marine species lack a dispersive stage and exist as a series of effectively closed local populations (e.g review by Knowlton \& Jackson 1993). These taxa may be highly differentiated genetically, presumably through the combined effects of genetic drift (founder effects), mutation and site-specific natural selection (e.g. Burton 1986, Ward 1990, Hunt 1993). This latter group comprises (1) sexually reproducing taxa that have limited dispersal, resulting in 'inbred', highly subdivided populations which are characterised by consistent deficits of heterozygotes (as compared with expectations for HardyWeinberg equilibria; so-called Wahlund effects, see Wallace 1981, Johnson \& Black 1984); and (2) asexually reproducing clonal species, in which successful clones may be highly replicated. These taxa are characterised by the presence of large numbers of individuals with identical multi-locus (clonal) genotypes (e.g. Ayre 1984, Burnett et al. 1995), and by both deficiencies and excesses of heterozygotes (e.g. Ayre \& Willis 1988, Ayre et al. 1991). Consequently, genetic evidence (the level of genetic diversity, the amount of genetic subdivision, and the pattern of deviation from Hardy-Weinberg equilibrium) can reveal substantial information on the mode of reproduction and dispersal capabilities.

Several widespread coral species display local and geographic variation in their skeletal morphology and life history. This variation could simply reflect high levels of phenotypic plasticity along environmental gradients (e.g. Dustan 1979, Foster 1979, Rosen 1981, Willis 1985). However, spatial variation in phenotypic traits could also reflect genetic differentiation within a single species (due to natural selection, or genetic drift). For example, the brooding pocilloporid coral Seriatopora hystrix exhibits extremely high levels of genetic differentiation among 12 neighbouring reefs along $90 \mathrm{~km}$ of the central Great Barrier Reef (GBR) (Ayre \& Dufty 1994). Similarly, Pocillopora damicornis shows marked differences in genetic composition among 3 adjacent habitats on One Tree Reef on the southern GBR, while another brooder, Acropora palifera, is genetically uniform (Benzie et al. 1995).

In some cases, intraspecific variation in the morphology and life histories of corals could be more apparent than real, arising from the incorrect 'lumping' of cryptic species. For example, sympatric morphs of Montipora digitata were separated into 2 species on the basis of fixed gene differences and non-compatible breeding systems (Stobbart \& Benzie 1994, Willis et al 1997). The taxonomic status of a dominant Caribbean coral, Montastrea annularis, may also require revision, and the conflicting evidence for and against splitting it illustrates some of the complexity of coral taxonomy and evolution. Three recognizable morphs differ electrophoretically, in isotopic ratios, and in their competitive ability (Knowlton et al. 1992, Van Veghel \& Bak 1993, Weil \& Knowlton 1994). However, the morphs overlap broadly in depth distribution, and colonies exhibit gradual phenotypic changes following experimental transplantation (Dustan 1979, Foster 1979). Knowlton et al. (1992) concluded that 1 morph was sufficiently genetically distinct to be a separate species, but another genetic study concluded that they were all conspecific (Van Veghel \& Bak 1993). Furthermore, differences in stable isotopic composition between morphs (Knowlton et al. 1992) are less than seasonal variation within single specimens (Fitt et al. 1993), and the timing of gamete release in each morph overlaps (Van Veghel 1994). Most importantly, gametes of the 3 morphs are interfertile in breeding experiments (Szmant et al. 1997). It is debatable whether current estimates of global coral diversity are too high because of rampant synonymy of intraspecific variants (Veron 1986), or too low because of undescribed, sibling species (Knowlton \& Jackson 1994). Furthermore, the nature of species boundaries in corals is unclear: many previously described, morphologically distinct species can potentially interbreed during mass-spawning events (see review by Willis et al. 1997).

The brooding (viviparous) coral Pocillopora damicornis is one of the most widespread and most variable hermatypic corals. Found throughout the tropical IndoPacific, it also occurs across a broad range of habitats and depths (e.g. Done 1982, Veron \& Pichon 1986, Richmond 1987a). Previous work with the hermaphroditic $P$. damicornis has yielded diverse and often conflicting descriptions of its life history. In particular, con- 
troversy surrounds the mechanisms of sexual and asexual reproduction in this species, and studies to date have reported surprising geographic variation in the relative contribution that asexual reproduction makes to recruitment and dispersal (see Stoddart \& Black 1985, Ward 1992, Benzie et al. 1995). Species with mixed modes of reproduction are expected to invest more energy in asexual reproduction where their habitat is relatively simple and stable and when intraspecific competition is low (Williams 1975, Bell 1982,1988 ). The causes of geographic variation in the relative importance of sexual and asexual recruitment in P. damicornis is uncertain. However existing reports of reliance on asexually derived recruitment have assessed populations at the edge of its geographical range (see below), where conditions may be expected to be physically stressful but competition is reduced (see Glesener \& Tilman 1978 for parallel terrestrial examples).

The life-history traits reported for Pocillopora damicornis vary greatly among regions of the Indo-Pacific. Like many corals, individual colonies of $P$. damicornis may reproduce asexually by extrinsic fragmentation (e.g. reviews by Highsmith 1982, Hughes et al. 1992). In the Eastern Pacific, large clones of $P$. damicornis spread vegetatively through rapid growth, fragmentation, and localised tumbling of fragments, while larval recruitment is relatively uncommon (Richmond 1987a). In contrast in the Western and Central Pacific, colonies grow less rapidly, are generally smaller and produce fewer fragments, while larval recruits a re highly abundant (e.g. Connell 1973, Grigg \& Maragos 1974, Richmond 1987 a). Sexual reproduction in viviparous corals, such as $P$. damicornis, involves internal fertilisation and subsequent brooding of planulae (Ayre \& Resing 1986, Harrison \& Wallace 1990). In Western Australia and Hawaii, larvae of $P$. damicornis are genotypically identical to their broodparents, and hence must be generated asexually (Stoddart 1983, 1984a, b, 1988). In contrast to fragments, asexually produced planulae are planktonic and potentially can be widely dispersed. In Western Australia and Hawaii, local populations are dominated by a small number of clones (highly replicated multi-locus genotypes) generated by asexually produced planulae. Nonetheless, high levels of genotypic diversity and histological data imply that sexual spawning also occurs (Stoddart \& Black 1985, Stoddart 1988, Ward 1992). In contrast, Benzie et al. (1995) found no evidence of asexual replication of genotypes in $P$. damicornis on One Tree Island reef, at the southern tip of the GBR.

In the present study, we describe a hierarchical survey of genetic variation within local and widely separated populations of Pocillopora damicornis on the GBR. This is the first large-scale survey of genetic vari- ation in any coral, with the following objectives: (1) to establish the relative contribution of sexual and asexual reproduction to recruitment along a large-scale latitudinal gradient from $14^{\circ}$ to $23^{\circ} \mathrm{S}$; (2) to test for evidence of genetic subdivision between sites ( 1 to $2 \mathrm{~km}$ apart) and between reefs up to $1200 \mathrm{~km}$ apart; and (3) to infer levels of gene flow at 2 spatial scales, within and among reefs, as revealed by the observed patterns of genotypic variation.

\section{MATERIALS AND METHODS}

Collection and storage of specimens. In order to test for spatial variation in the genetic compostion of PocilJopora damicornis along the GBR we made collections within 3 reef crest sites at each of 3 locations (reefs) separated by up to $1195 \mathrm{~km}$. The sampled reefs were Lizard Island $\left(14^{\circ} 40^{\prime} \mathrm{S}, 145^{\circ} 28^{\prime} \mathrm{E}\right)$, Davies Reef $\left(18^{\circ} 50^{\prime} \mathrm{S}, 147^{\circ} 38^{\prime} \mathrm{E}\right) 490 \mathrm{~km}$ to the south, and Heron Island $\left(23^{\circ} 27^{\prime} \mathrm{S}, 151^{\circ} 55^{\prime} \mathrm{E}\right)$ a further $705 \mathrm{~km}$ to the south (Fig. 1). At each site we collected tissue samples (branch fragments) from 39 to 48 adult $P$. damicornis $\left[x=45 \pm 1\right.$ (SE)], from reef areas averaging $390 \mathrm{~m}^{2}$ and at depths of 1 to $4 \mathrm{~m}$. We took care to avoid collection of multiple fragments from colonies that had clearly undergone recent fission or fragmentation (i.e. appeared to share the same skeletal mass). Consequently, evidence of a clonal population structure in our collections would indicate that $P$. damicornis produces asexual planulae on the GBR. Samples were collected between February 1992 and January 1993 and placed in liquid nitrogen until final storage in the laboratory at $-80^{\circ} \mathrm{C}$ pending electrophoresis.

Electrophoresis. In order to estimate levels and patterns of genotypic diversity and allele frequencies at each site, we used allozyme electrophoresis to determine the genotypes of each colony for each of 6 enzyme systems and a total of 7 variable enzymeencoding loci. Electrophoretic methods were modified from Harris \& Hopkinson (1976) and Richardson et al. (1986). Assays were conducted using horizontal starch $(11 \% \mathrm{w} / \mathrm{v})$ gels. Tissue extraction and assay conditions were as described by Willis \& Ayre (1985) except that the extractant solution contained $0.014 \mathrm{M}$ Tris- $\mathrm{HCl}$. Electrophoretic buffers and assay conditions followed Selander et al. (1971): on buffer number 5, malate dehydrogenase (MDH; E.C.\#1.1.1.37) and mannose-phosphate isomerase (MPI; E.C.\#5.3.1.8); on buffer number 6 , leucyl-proline peptidase (LPP; E.C. \#3.4.11) and leucyl-tyrosine peptidase (LTP; E.C. \#3.4.11); and on buffer number 9, glucose-phosphate isomerase (GPI; E.C.\#5.3.1.9) and phosphoglucomutase (PGM; E.C.\#2.7.5.1). All enzymes were apparently monomeric or dimeric, and isozyme patterns 


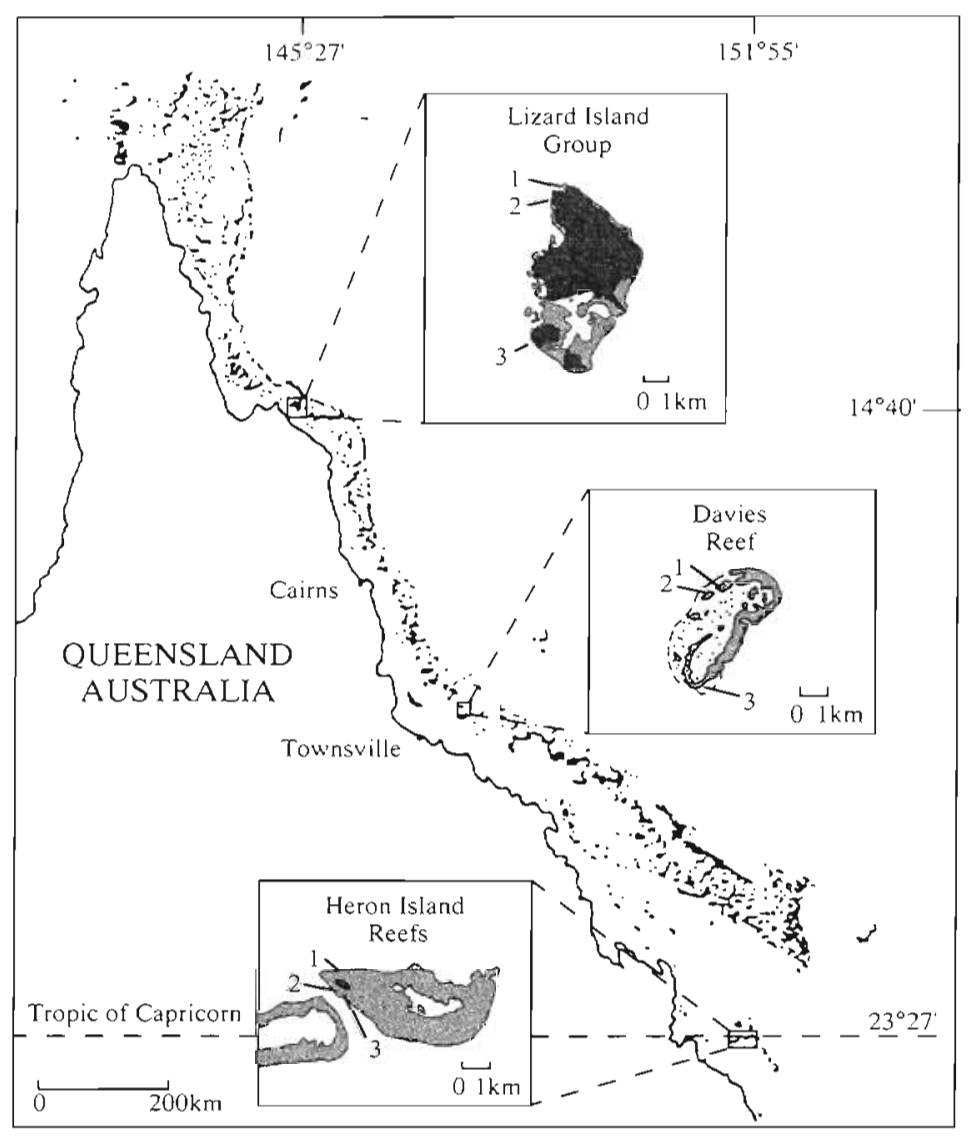

Fig. 1. Map of northeast coast of Australia showing location of Pocillopora damicornis collection sites along the Great Barrier Reef Lizard Island Reef: 1, North Reef ${ }_{i} 2$, Granite Bluff; 3, Palfrey Island. Davies Reef: 1, Back Reef 1; 2, Back Reef 2; 3, Reef Crest. Heron Island Reef: 1, North Crest; 2, South Crest 1; 3, South Crest 2. Site numbers correspond with those in the tables and text. Lizard Island Reef: dark shading = continental islands, light shading $=$ fringing reef; Davies Reef: light shading $=$ platform reef; Heron Island Reef: dark shading $=$ cay, light shading $=$ platform reef; in all 3: no shading = lagoon or water surrounding reef

Analyses. Effects of reproductive mode and dispersal on genotypic variation: We first assessed the magnitude and direction of departures from Hardy-Weinberg equilibrium to infer the effects of reproductive mode (sexual versus asexual planulae) and dispersal on the genotypic composition of populations. These departures were expressed as Wright's (1978) fixation index $f$, where positive and negative values represent deficits or excesses of heterozygotes respectively, compared to expectations for Hardy-Weinberg equilibria. $\chi^{2}$ tests were employed to assess the significance of departures from expected numbers of heterozygotes and homozygotes. The sequential Bonferroni technique (Hochberg 1988) was used throughout the analyses to correct for the large number of similar tests (to reduce the chance of type I errors). The correction was applied using a DBASE program (Lessios 1992) which calculates an exact probability value for each $\chi^{2}$ value from the incomplete gamma function.

In order to determine whether each locus behaved independently, we tested each pairwise combination of loci for linkage disequilibria using Hill's (1975) multi-allelic measure $D$. Significant inter-locus associations may result (1) from the physical linkage of loci (indicated by similar patterns of linkage within each collection), which would invalidate their use as independent measures of genotypic diversity and population structure, or (2) from episodes of inbreeding, asexual reproduction, random drift, selection, mutation or the mixing of genetically distinct populations (where interlocus associations will vary among subpopulations) (Crow \& Kimura

were similar to those described for other species with normal Mendelian inheritance (e.g. Richardson et al. 1986). Between 3 and 7 alleles were detected at each locus (Table 1) and alleles were described by the ratio of their electrophoretic mobility relative to that of the most common allele. These loci were selected following screening of 14 enzymes on 6 buffer systems using samples from Heron Island. Rejected loci (including $M d h^{-2}$ and $6 P g d$ (E.C.\#1.1.1.44)) produced no detectable activity or yielded zymograms that were not consistently resolvable. Although Pocillopora damicornis is the host for symbiotic zooxanthellae in comparisons of 'bleached' (zooxanthellae depleted) and normal tissue and concentrated algal pellets, Stoddart (1983) detected no contribution of zooxanthellae to activity for each of the loci that we assayed.
1970, Hedrick et al. 1978). In this study, only 3 cases of the 122 pairwise tests for interlocus association between variable loci revealed statistically significant linkage disequilibria ( $p<0.05$ ), and none of these remained significant after application of a Bonferroni correction.

We used 2 approaches to infer the relative frequencies of sexually and asexually derived adults within each collection. Firstly, for each of the 9 sites we determined the multi-locus genotype of each colony ( $N=$ 39 to 48 ) and then we counted the number of unique genotypes $N_{\mathrm{g}}\left(N_{\mathrm{g}} \leq N\right)$. Because only a small portion of the genome can be sampled electrophoretically, colonies that were genotypically identical (for these loci) may still be non-clonemates. Therefore, the ratio $N_{\mathrm{g}}: N$ provides a maximum estimate of the contribution of asexual reproduction to localised recruitment. Sec- 
ondly, we compared the ratio of observed multi-locus genotypic diversity $\left(G_{0}\right)$ to that expected under conditions of sexual reproduction with free recombination $\left(G_{e}\right)$, as described by Stoddart \& Taylor (1988). In applying this approach we assume that Pocillopora damicornis will recruit either via locally generated (asexual) propagules or either locally produced or widely dispersed sexual propagules. Departures of $G_{0}: G_{\mathrm{e}}$ from unity should reflect the combined effects of departures from single-locus Hardy-Weinberg equilibria and multi-locus linkage disequilibria. Such departures are a predictable consequence of asexual reproduction (but will also result from other factors such as population subdivision). In contrast, a genetically variable population with high levels of sexually derived recruitment will display a $G_{0}: G_{e}$ ratio of close to unity. We then assessed the statistical significance of differences between $G_{0}$ and $G_{e}$ using an unpaired $t$-test (Stoddart \& Taylor 1988).

Population subdivision and inferred gene flow: In order to quantify levels of population subdivision, we used a hierarchical analysis of standardised genetic variance $(F)$ statistics (Wright 1969) to partition genetic variation within and among reefs. Values of $F$ were expressed as weighted averages across alleles and loci, and these were adjusted by the subtraction of the binomial sampling variance for each allele. Subscripts are used to denote the source of variation, i.e. $F_{\mathrm{SL}}=$ variation among sites within location (within reefs); $F_{L T}=$ variation among locations (between reefs); and $F_{\mathrm{ST}}=$ total variation among all sites. We calculated these parameters using the formulations of Weir \& Cockerham (1984) (i.e. standardised genetic variance $=$ ө) using the program Diploid (Weir 1990) which executes numerical resampling via jackknifing to provide estimates of variance for each locus and bootstrapping to provide estimates of variances across loci. Values for $\theta$ should range from zero (i.e. no variation among sites due to complete panmixia) to a theoretical maximum of 1 (i.e. populations fixed for alternative alleles). However, Weir (1990) notes that in cases where $\theta$ is close to zero, negative values may be obtained.
Table 1. Pocillopora damicornis. Allele frequencies for each of 7 enzyme encoding loci, based on an electrophoretic survey of 9 collections of 39 to 48 colonies from 3 locations (reefs) on the GBR (Great Barrier Reef). See Table 3 for sample sizes and Fig. 1 for collection sites

\begin{tabular}{|c|c|c|c|c|c|c|c|c|c|}
\hline \multirow{2}{*}{ Locus } & \multicolumn{3}{|c|}{ Lizard Island Reef } & \multicolumn{3}{|c|}{ Davies Reef } & \multicolumn{3}{|c|}{ Heron Island Reef } \\
\hline & 1 & 2 & 3 & 1 & 2 & 3 & 1 & 2 & 3 \\
\hline \multicolumn{10}{|l|}{$G p i^{-t}$} \\
\hline 2.70 & - & 0.09 & - & 0.01 & 0.07 & - & 0.01 & 0.07 & 0.04 \\
\hline 2.20 & 0.01 & 0.04 & 0.06 & 0.05 & 0.01 & - & 0.03 & 0.01 & 0.05 \\
\hline 1.90 & 0.20 & 0.16 & 0.18 & 0.12 & 0.25 & 0.08 & 0.23 & 0.26 & 0.30 \\
\hline 1.50 & - & 0.02 & - & - & - & - & - & 0.02 & - \\
\hline 1.00 & 0.75 & 0.67 & 0.72 & 0.79 & 0.67 & 0.92 & 0.54 & 0.51 & 0.58 \\
\hline 0.50 & - & 0.02 & 0.01 & 0.02 & - & - & - & 0.02 & - \\
\hline 0.20 & 0.04 & - & 0.03 & 0.01 & - & - & 0.19 & 0.11 & 0.03 \\
\hline \multicolumn{10}{|l|}{$\mathrm{Pgm}^{-1}$} \\
\hline 1.50 & - & - & - & 0.02 & - & - & - & - & - \\
\hline 1.34 & 0.01 & 0.01 & - & 0.06 & - & - & - & - & - \\
\hline 1.19 & 0.07 & 0.02 & 0.04 & 0.20 & 0.04 & 0.29 & 0.03 & 0.02 & - \\
\hline 1.10 & 0.54 & 0.57 & 0.30 & 0.26 & 0.08 & 0.27 & 0.14 & 0.03 & 0.07 \\
\hline 1.00 & 0.37 & 0.37 & 0.65 & 0.43 & 0.87 & 0.42 & 0.83 & 0.95 & 0.93 \\
\hline 0.95 & 0.01 & 0.03 & 0.01 & 0.03 & 0.01 & 0.02 & - & - & - \\
\hline \multicolumn{10}{|l|}{$M d h^{-1}$} \\
\hline 1.12 & - & - & - & - & - & - & 0.02 & - & - \\
\hline 1.00 & 0.91 & 0.99 & 1.00 & 1.00 & 1.00 & 1.00 & 0.98 & 1.00 & 0.93 \\
\hline 0.88 & 0.09 & 0.01 & - & - & - & - & - & - & 0.07 \\
\hline \multicolumn{10}{|l|}{$M p i^{-1}$} \\
\hline 1.50 & - & 0.17 & - & 0.06 & - & 0.01 & - & - & 0.06 \\
\hline 1.18 & 0.08 & - & 0.03 & 0.14 & 0.05 & 0.10 & 0.02 & 0.07 & 0.02 \\
\hline 1.00 & 0.67 & 0.60 & 0.75 & 0.60 & 0.78 & 0.67 & 0.85 & 0.75 & 0.73 \\
\hline 0.91 & 0.24 & 0.23 & 0.22 & 0.20 & 0.17 & 0.22 & 0.13 & 0.18 & 0.18 \\
\hline 0.77 & 0.01 & - & - & - & - & - & - & - & 0.01 \\
\hline \multicolumn{10}{|l|}{$L p p^{-1}$} \\
\hline 1.15 & 0.04 & - & - & - & - & 0.04 & - & - & - \\
\hline 1.00 & 0.96 & 1.00 & 0.99 & 1.00 & 1.00 & 0.96 & 0.91 & 1.00 & 1.00 \\
\hline 0.93 & - & - & 0.01 & - & - & - & 0.09 & - & - \\
\hline \multicolumn{10}{|l|}{$L t p^{-2}$} \\
\hline 1.00 & 0.38 & 0.62 & 0.43 & 0.38 & 0.76 & 0.72 & 0.43 & 0.37 & 0.44 \\
\hline 0.90 & 0.21 & 0.19 & 0.35 & 0.33 & 0.20 & 0.28 & 0.48 & 0.37 & 0.48 \\
\hline 0.83 & 0.39 & 0.12 & 0.19 & 0.29 & 0.04 & - & 0.09 & 0.26 & 0.08 \\
\hline 0.78 & - & 0.06 & 0.03 & - & - & - & - & - & - \\
\hline 0.71 & 0.02 & 0.01 & - & - & - & - & - & - & - \\
\hline \multicolumn{10}{|l|}{$L t p^{-3}$} \\
\hline 1.10 & 0.02 & 0.10 & - & 0.07 & 0.04 & - & 0.08 & - & - \\
\hline 1.00 & 0.87 & 0.80 & 0.83 & 0.87 & 0.96 & 1.00 & 0.82 & 0.98 & 1.00 \\
\hline 0.90 & 0.08 & 0.10 & 0.16 & 0.05 & - & - & 0.10 & 0.02 & - \\
\hline 0.80 & 0.03 & - & 0.01 & 0.01 & - & - & - & - & - \\
\hline
\end{tabular}

\section{RESULTS}

\section{Genetic variation}

Samples from all 9 sites ( $n=407$ colonies) were both genetically and genotypically diverse, with few clear patterns of geographic variation in allele frequencies or levels of genetic diversity (Table 1). The total number of alleles in all collections for the 7 enzyme encoding loci was 33. Thirty of these were found at Lizard Island, while Davies Reef and Heron Island Reef each 
had 26. Variability was greatest within reefs, with the number of alleles/site ranging from 22 to 25 at Lizard Island, 16 to 25 at Davies Reef, and 19 to 22 at Heron Island Reef. Most of the 'missing' alleles were rare everywhere. Four of the 7 loci we examined were highly variable $\left(\mathrm{GPi}^{-1}, \mathrm{Pgm}^{-1}, \mathrm{Mpi}^{-1}\right.$, and $\left.\mathrm{Ltp}^{-2}\right)$, each displaying between 5 and 7 alleles. The remaining loci, $M d h^{-1}, L p p^{-1}$, and $L t p^{-1}$, were much less variable, and the frequency of their most common allele was always $>80$ to $90 \%$ (Table 1 ). Among the variable loci, most alleles were detected in collections from each reef. However, for 2 of these loci $\left(\mathrm{Pgm}^{-1}\right.$ and Ltp $\left.{ }^{-2}\right)$ the frequency of the most common allele varied both within and among reefs. For example, the frequency of the the $\mathrm{Pgm}^{-1}$ allele 1.10 was consistently high at the 3 within-reef sites at Lizard Island (30 to $54 \%$ ), consistently low at Heron Island ( 3 to $14 \%$ ), and ranged widely at Davies Reef (from 8 to $27 \%$ ). Similarly, $L t^{-2}$ allele 0.83 varied from zero to $29 \%$ at Davies Reef, and up to $39 \%$ at Lizard Island.

\section{Patterns of genotypic diversity}

Genotype frequencies for at least 1 (and up to 3) of the 7 loci differed significantly from expectations for Hardy-Weinberg equilibria at 8 of the 9 sites $\left(\chi^{2}\right.$ test for goodness of fit: $\mathrm{p}<0.05$; Table 2). Two loci, $\mathrm{Mpi}^{-1}$ and $L t p^{-2}$, deviated significantly at all 3 reefs, and at 6 of the 9 sites. $\mathrm{Pgm}^{-3}$ differed significantly at a single site on both Lizard Island and Heron Island, while Ltp $\mathrm{p}^{-3}$ also showed a significant departure at 1 of the Lizard Island sites. Only 1 locus, $G p^{-1}$, represented by 7 alleles, conformed to Hardy-Weinberg equilibria at all 9 locations. A further 2 loci, $M d h^{-1}$ and $L p p^{-1}$, were insufficiently variable to analyze statistically. Excluding these 2, 2 to 4 of the 5 remaining loci deviated significantly at each reef.

Asexual reproduction (whether it occurs extrinsically through fragmentation or through the intrinsic production of mobile larvae) should produce both deficiencies and excesses of heterozygotes (e.g. Ayre \& Willis 1988, Ayre et al. 1991). However, in this study deficits of heterozygotes were 4 times more common than excesses (41 vs 10), and all 15 statistically significant deviations from Hardy-Weinberg equilibria were produced by deficits (Table 2). Deficits of heterozygotes may result from either spatial subdivision due to limited dispersal of gametes or larvae, or from inbreeding (including self-fertilisation). The effects of spatial subdivision are predictable as a Wahlund effect where the magnitude of the deficiency should equal the inter-deme variation in allele frequencies [ $\Sigma \sigma^{2} /\left(H_{\mathrm{e}}-H_{0}\right)$, where $H_{\mathrm{e}}$ is the proportion of heterozygotes expected within a panmictic population, and $H_{0}$ is the average proportion of heterozygotes observed within each deme (Wallace 1981)]. However, in this study the observed variation among collections was sufficient to explain only $18 \pm 7 \%(x \pm S E)$ of heterozygous deficits.

Within each site, most individuals displayed unique 7 -locus genotypes (Table 3), which further supports the hypothesis that localised asexual reproduction had made little or no contribution to recruitment. Indeed, all of the 9 collections displayed approximately the levels of multi-locus genotypic diversity expected for samples drawn from exclusively sexually reproducing populations with random mating. Levels of 7 -locus genotypic richness were high $\left[N_{\mathrm{g}}: N=0.80 \pm 0.05(\mathrm{SE})\right]$, and the observed levels of genotypic diversity were

Table 2. Pocillopora damicornis. Wright's fixation index for 9 collections from the GBR, for each of 7 enzyme encoding loci. Significant departures from Hardy Weinberg equilibria are noted (after Bonferroni correction) as " $p<0.05, \cdots p<0.01, \cdots p<0.001$; nd: $\chi^{2}$ not determined as locus was insufficiently variable; (-) locus monomorphic for population

\begin{tabular}{|c|c|c|c|c|c|c|c|c|c|}
\hline \multirow[b]{2}{*}{ Locus } & \multicolumn{3}{|c|}{ Lizard Island Reef } & \multicolumn{3}{|c|}{ Davies Reef } & \multicolumn{3}{|c|}{ Heron Island Reef } \\
\hline & 1 & 2 & 3 & 1 & 2 & 3 & 1 & 2 & 3 \\
\hline$G p i^{-1}$ & +0.064 & +0.128 & -0.089 & +0.022 & -0.052 & -0.082 & +0.014 & +0.045 & -0.159 \\
\hline$M d h^{-1}$ & -0.098 & $\begin{array}{c}-0.011 \\
\text { nd }\end{array}$ & $(-)$ & $(-)$ & $(-)$ & $(-)$ & $\begin{array}{c}-0.022 \\
\text { nd }\end{array}$ & $(-)$ & -0.079 \\
\hline $\mathrm{Mpi}^{-1}$ & +0.864 & +0.534 & +0.527 & +0.877 & +0.942 & +0.600 & +0.011 & +0.584 & +0.181 \\
\hline$L p p^{-1}$ & $\begin{array}{r}+1.0 \\
\text { nd }\end{array}$ & $(-)$ & $\begin{array}{c}-0.013 \\
\text { nd }\end{array}$ & $(-)$ & $(-)$ & $\begin{array}{c}-0.045 \\
\text { nd }\end{array}$ & +0.452 & $(-)$ & $(-)$ \\
\hline lt $p^{-2}$ & +0.328 & +0.537 & +0.371 & +0.533 & +0.670 & +0.571 & +0.281 & +0.367 & +0.199 \\
\hline Ltp ${ }^{-3}$ & +0.328 & +0.537 & +0.818 & +0.799 & $\begin{array}{c}0.478 \\
\text { nd }\end{array}$ & $(-)$ & +0.522 & $\begin{array}{r}+1.0 \\
\text { nd }\end{array}$ & $(-)$ \\
\hline $\mathrm{Pgm}^{-1}$ & +0.291 & +0.559 & +0.258 & +0.288 & +0.081 & +0.220 & +0.707 & $\begin{array}{c}+0.375 \\
\text { nd }\end{array}$ & +0.538 \\
\hline
\end{tabular}


Table 3. Pocillopora damicornis. Comparison of observed and expected multi-locus genotypic diversity for 9 collections from the GBR. $N$ : no. of individual colonies; $N_{\mathrm{g}}$ : no. of unique multi-locus genotypes; $G_{0}$ : observed multi-locus genotypic diversity; $G_{c}$ : expected multi-locus genotypic diversity (see text for additional details). In each case $G_{n}: G_{\mathrm{e}}$ was not significantly different to 1 ; unpaired $t$-test, $p>0.05$

\begin{tabular}{|c|c|c|c|c|c|c|c|}
\hline $\begin{array}{c}\text { Location } \\
\text { Site }\end{array}$ & $N$ & $N_{\mathrm{g}}$ & $N_{\mathrm{g}}: N$ & $G_{0}$ & $G_{e}$ & $\begin{array}{c}G_{0} \\
(\mathrm{SD})\end{array}$ & $G_{0}: G_{e}$ \\
\hline \multicolumn{8}{|c|}{ Lizard Island Reef } \\
\hline 1 & 45 & 43 & 0.96 & 41.33 & 40.97 & 3.96 & 1.01 \\
\hline 2 & 46 & 39 & 0.85 & 33.06 & 41.93 & 3.74 & 0.79 \\
\hline 3 & 39 & 34 & 0.87 & 29.82 & 32.67 & 4.38 & 0.91 \\
\hline \multicolumn{8}{|c|}{ Davies Reef } \\
\hline 1 & 42 & 39 & 0.93 & 36.75 & 39.50 & 2.87 & 0.93 \\
\hline 2 & 47 & 28 & 0.60 & 14.07 & 19.41 & 4.66 & 0.73 \\
\hline 3 & 46 & 25 & 0.54 & 17.07 & 27.24 & 4.87 & 0.63 \\
\hline \multicolumn{8}{|c|}{ Heron Island Reef } \\
\hline 1 & 46 & 41 & 0.89 & 37.79 & 37.19 & 5.29 & 1.02 \\
\hline 2 & 48 & 36 & 0.75 & 25.60 & 33.26 & 5.46 & 0.77 \\
\hline 3 & 48 & 38 & 0.79 & 32.00 & 28.99 & 5.78 & 1.10 \\
\hline $\begin{array}{l}\text { Mean } \\
\pm \mathrm{SE}\end{array}$ & $\begin{array}{r}45.2 \\
\pm 0.98\end{array}$ & $\begin{array}{c}35.9 \\
\pm 1.99\end{array}$ & $\begin{array}{c}0.80 \\
\pm 0.05\end{array}$ & $\begin{array}{l}29.72 \\
\pm 3.09\end{array}$ & $\begin{array}{l}33.46 \\
\pm 2.46\end{array}$ & & $\begin{array}{c}0.88 \\
\pm 0.05\end{array}$ \\
\hline
\end{tabular}

never significantly different from expectations for sexual reproduction (i.e. average $G_{0}: G_{e}=0.88 \pm 0.05 ; \mathrm{p}>$ 0.05 after application of Bonferroni correction; Table 3). The lowest $G_{0}: G_{\mathrm{e}}$ ratio was 0.63 at Site 3 on Davies Reef (unpaired $t$-test, not significant, $p>0.05$ ). and even here the 46 colonies we sampled displayed 25 distinct 7 -locus genotypes. Of these, 15 were represented by only 1 colony, 4 were found twice, and only 6 occurred more frequently.

\section{Population subdivision and gene flow}

On average the total level of variation among all sites was relatively modest $\left[7\right.$-locus mean $( \pm \mathrm{SD}) F_{\mathrm{ST}}=0.084$ \pm 0.038 ; Table 4 ]. Most (67\%) of the variation occurred among sites within locations (i.e. within reefs, mean $F_{\mathrm{SL}}=0.057$ ) and only $33 \%$ among the 3 widely separated locations (between reefs, $F_{L T}=0.027$ ). Heterogeneity $\chi^{2}$ tests revealed statistically significant heterogeneity among collections for 3 of the 7 loci, Gpir-1, $L t p^{-1}$ and $P g m^{-1}(\mathrm{p}<0.01) . M d h^{-1}, L p p^{-1}$, and $L t p^{-3}$ had insufficient variability for statistical analysis, while $\mathrm{Mpi}^{-1}$ showed little variation at any spatial scale (Tables $1 \& 4$ ). Levels of variation were usually similar for comparisons among reefs and loci. However, allele frequencies at the $\mathrm{Pgm}^{-1}$ locus were by far the most variable with an $F_{\mathrm{ST}}$ of $0.208 \pm 0.049$ (cf. 0.013 to 0.072 for the remaining 6 loci, Table 4), possibly due to sitespecific natural selection. Excluding this locus, the 6locus mean $F_{S T}$ was slightly lower at $0.055 \pm 0.029$, with little variation detected among reefs $\left(F_{L T}=0.008 \pm\right.$ 0.014) (Table 4).

The magnitude of current levels of gene flow $\left(N_{\mathrm{e}} m\right)$ among the 9 populations of Pocillopora damicornis may be estimated as $\left[\left(1 / F_{\mathrm{ST}}\right)-1\right] / 4$, based on Wright's (1969) island model, where $N_{\mathrm{e}}$ is the genetically effective size of each subpopulation and $m$ is the proportion of migrants per generation. Application of this approximation (for all loci excluding $\mathrm{Pgm}^{-1}$ ) yielded estimates of gene flow ranging from 2.6 to 6.9 effective migrants per generation among sampling sites (within reefs) and 31 effective migrants per generation among locations (between reefs).

Table 4. Pocillopora damicornis. Hierarchical analysis of standardised genetic variation (expressed as Weir \& Cockerham's (1984) $\theta$ | within and among locations (reefs). Comparisons were made among 3 sites within each of 3 reefs, among the 3 reefs, and among all sites. Values are weighted averages \pm SD (calculated by resampling via jackknifing to provide estimates of variance for each locus and bootstrapping to provide estimates of variances across loci). Statistically significant heterogeneity of allele frequencies among sites indicated by $\cdots p<0.01, \cdots p<0.001$. nd: $\chi^{2}$ not determined as locus was insufficiently variable

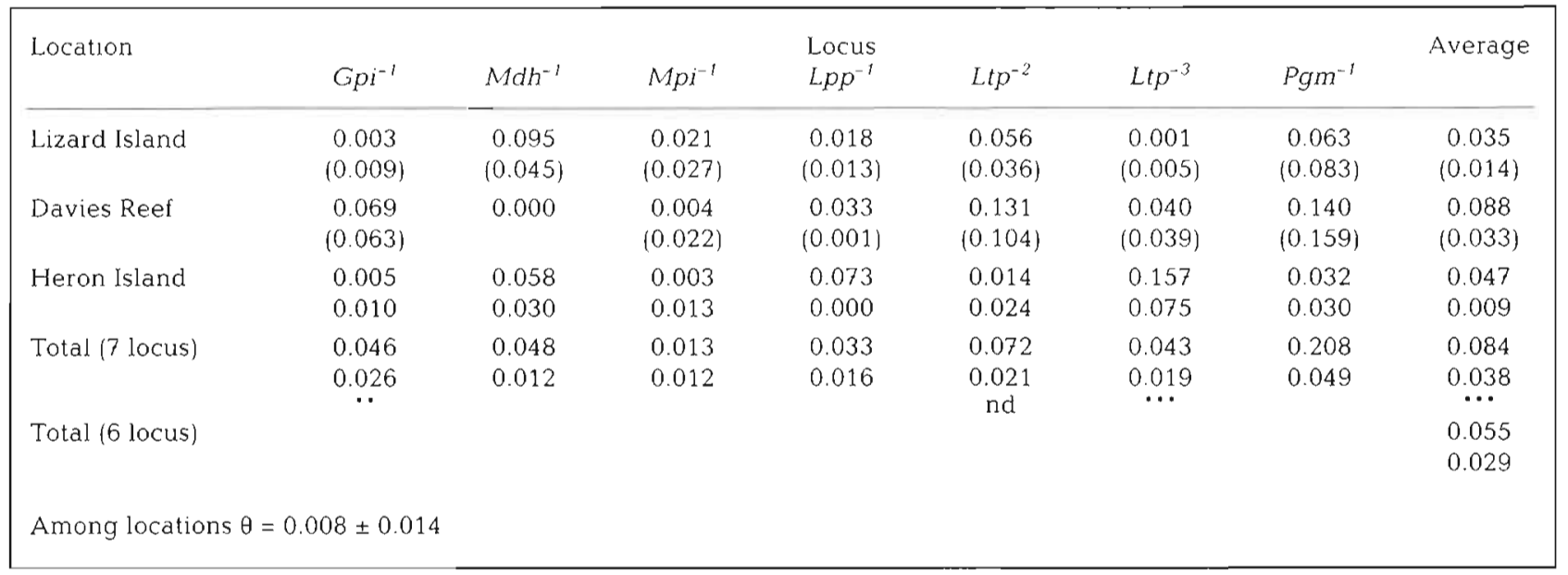




\section{DISCUSSION}

Our analysis of the levels of genetic variation within and among reef crest populations of Pocillopora damicornis implies that Australia's GBR supports a single, genetically homogeneous, breeding population that is strongly interconnected by high levels of gene flow. Moreover, we found that single and multi-locus genotype frequencies at all sites matched expectations for recruitment via sexual reproduction. Taken together, these findings show that $P$. damicornis displays a relatively uniform life-history strategy on reef crests along the length of the world's longest reef system. Moreover, large-scale genetic differentiation in $P$. damicornis was relatively low compared to local variation (Table 4). Even lower levels of genetic variation among widely spread local populations have been described from the GBR for 2 species of starfish. Acanthaster planci (Benzie \& Stoddart 1992) and Linckia laevigata (Williams \& Benzie 1993), 3 species of the giant clam Tridacna (Benzie 1994), the zoanthid Palythoa caesia (Burnett et al. 1994), and for 2 species of reef fish that have long-lived larvae (Doherty et al. 1995). Conversely, much higher levels of genetic variation among reefs have been reported for the brooding coral Seriatopora hystrix (Ayre \& Dufty 1995), the clonal zoanthid Zoanthus copperingeri (Burnett et al. 1995), and 5 species of fish with relatively short larval durations (Doherty et al. 1995).

\section{Relative importance of sexual and asexual reproduction for recruitment}

Our data strongly imply that localised asexual recruitment played little or no part in the maintenance of extant local populations of Pocillopora damicornis, and that such populations are maintained by the recruitment of sexually generated larvae. Although we cannot exclude the possibility that some low level of localised asexual recruitment occurs, we found that samples from each of the 9 sites on the reef crests of 3 widely separated mid-shelf reefs were genotypically diverse, with $80 \%$ of coral colonies displaying unique multi-locus genotypes. Indeed, on average we detected $88 \%$ of the level of multi-locus genotypic diversity $\left(G_{0}\right)$ expected for randomly mating populations with exclusively sexual reproduction. Singlelocus genotype frequencies were often significantly different from values predicted for Hardy-Weinberg equilibria. However, these departures were always due to deficits of heterozygotes, whereas the recruitment of asexual planulae as described elsewhere for this species (Stoddart 1984a) would be expected to produce both excesses and deficits (Ayre 1984).
It could be argued that the high level of genotypic diversity within our collections arose through the continued asexual replication of a vast number of preexisting, well mixed or infrequently generated clones. However, this seems improbable as it would require either that (1) asexually produced planulae settle far from their brood parents and the population is effectively panmictic or (2) asexually produced planulae settle locally in small numbers, and all clones are equally successful. Neither of these scenarios conforms to theoretical predictions for the evolution and maintenance of clonal populations (e.g. Williams 1975, Maynard Smith 1978, Bell 1982) or previous accounts of the highly localised distribution of Pocillopora damicornis clones within populations that produce planulae asexually (Stoddart 1984b, 1988).

The consistently large deficits of heterozygotes that we detected at 4 of the 5 most variable loci seem most likely to be a consequence either of inbreeding (e.g. self-fertilisation) or spatial or temporal subdivision of Pocillopora damicornis populations (Wahlund effects). Self-fertilisation would provide the simplest explanation for the heterozygous deficits although it would be necessary to infer a mechanism such as heterosis to account for the lack of deficits for Gpi. However, little is known about the self-compatibility of brooding corals. Highly variable levels of self-fertilisation have been demonstrated in the laboratory in experimental crosses of several broadcast spawning species (e.g. Willis et al. 1997). In nature, however, unfertilised eggs from many colonies are released simultaneously in egg-sperm bundles that break apart and are rapidly diluted at the water surface. The gametes typically remain viable for 5 to 6 h (Harrison \& Wallace 1990), during which they are more likely to outcross than self-fertilise. Furthermore the vast number of sperm produced by corals (the mass of testes in a colony can exceed that of eggs; Hall \& Hughes 1994) is almost certainly a mechanism to promote outcrossing.

Assuming that outcrossing is the norm, a simple spatial Wahlund effect may account for some of the heterozygous deficiencies seen in Pocillopora damicornis. Spatial variation in allele frequencies were estimated to be sufficient to account for $64 \%$ of heterozygous deficits via Wahlund effects in another brooding pocilloporid, Seriatopora hystrix (Ayre \& Dufty 1994). However, for $P$. damicornis we calculated that only $18 \pm 7 \%$ of heterozygous deficiencies may be explained in this way (estimated from the variance of allele frequencies among individual collections). However, because recruitment and dispersal in $P$. damicornis is likely to be complex (see below), this calculation is at best an approximation. For example, since our sampling sites typically encompassed larger areas than would be 
expected for breeding groups defined by the dispersal of sperm, then we may expect to have underestimated fine-scale geographic variation (e.g. Johnson \& Black 1984). Such ubiquitous deficiencies of heterozygotes might also be attributable to temporal Wahlund effects (caused by multiple cohorts with differing allele frequencies), or to the incorrect lumping of 2 or more morphologically similar species. The latter explanation can be discounted, however, because it would require the relative abundance of each species to be the same at every site. Furthermore, the presence of 2 or more separate species gene pools would have been expected to be associated with striking linkage disequilibria (e.g Duffy 1993). A variety of other explanations exist for the occurrence of heterozygous deficits in marine and terrestrial organisms, including strong selection against heterozygotes (e.g. Borsa et al. 1992) and the presence of null alleles (e.g. Foltz 1986). However, these factors should not be expected to produce the observed large and consistent deficits at each of several apparently unlinked loci

Our findings closely match those of Benzie et al.'s (1995) study of small-scale genotypic variation in Pocillopora damicornis at sites up to 1 to $2 \mathrm{~km}$ apart on One Tree Island on the southern GBR, and Ayre \& Dufty's (1994) description of genotypic variation in the pocilloporid Seriatopora hystrix on 11 reefs further north. As in our study, $G_{0}: G_{e}$ ratios in each local population were not significantly less than 1 . These results contrast sharply with earlier descriptions of highly clonal population structures in $P$. damicornis from Western Australia and Hawaii (Stoddart 1984b, 1988), and with numerous other temperate and tropical clonal cnidarians that reproduce predominantly asexually [e.g. the coral Pavona cactus (Ayre \& Willis 1988), the sea anemones Actinia tenebrosa (Ayre 1984, Ayre et al. 1991), Metridium senile (Hoffmann 1986) and Anthothoe albocincta (Billingham \& Ayre 1996), and the zoanthid, Zoanthus copperingeri (Burnett et al. 1995)]. Populations of these latter taxa are characterised by $G_{0}: G_{e}$ ratios that are typically $<0.4$, and they often have both significant excesses and deficits of heterozygotes.

The use of genetic data to infer aspects of an organism's life history has the advantage of providing a cumulative measure of successful reproduction and recruitment within the sampled population in the current generation. Consequently, our data combined with those of Benzie et al. (1995) imply that in recent years asexual reproduction by planulae of Pocillopora damicornis was relatively unimportant on 4 intensively sampled mid-shelf reefs along the GBR. In interpreting these results, it is important to realise that we excluded highly localised asexual reproduction by fragmentation (i.e. we did not take separate samples from immediately adjacent colonies that appeared to be the prod- ucts of very recent fragmentation). Passive tumbling by fragments should rarely result in dispersal beyond a few meters (e.g. review by Highsmith 1982) and cannot play any role in enhancing levels of gene flow between sites or reefs. Furthermore, fragments of $P$. damicornis (or any other coral) that are generated on shallow, wave-swept reef crests very rarely reattach and survive. For example, within permanently marked plots on the reef crest at Heron Island, there has been no successful establishment of fragments of $P$. damicornis from 1963 to the present, although continuous larval recruitment by this species has accounted for over $40 \%$ of the total for all corals (Connell 1973, Connell \& Hughes unpubl. data). Similarly, although $P$.damicornis is abundant on the reef crest at Lizard Island, it comprised only $3 \%$ of 394 fragments that tumbled into twenty $4 \mathrm{~m}^{2}$ plots there over 2 yr. Of the fragments, $87 \%$ died within 3 mo of first being detected, including all of the Pocillopora (Nelson 1994). However, P. damicornis also occurs in other, less-exposed reef habitats and in deeper water (Veron \& Pichon 1976), where fragmentation is likely to be a more successful means of highly localised, vegetative propagation following extrinsic breakage of the skeleton.

Life-history theory predicts that intrinsic asexual reproduction (e.g. of planulae) will be most favoured when the environment is relatively homogeneous, biotic stresses are low and mortality is density-independent (i.e. competitive pressures are low). Conversely, sexual reproduction should be favoured as a means of escaping from crowded environments to newly cleared patches elsewhere (Williams 1975, Glesener \& Tilman 1978, Maynard Smith 1978, Bell 1982, 1988, Karlson et al. 1996). Regional variation in the lifehistory traits of Pocillopora damicornis appears to fit these predictions: localised asexual recruitment either via planulae or fragmentation appears to assume great importance at the margins of its geographic range (Eastern Pacific, Hawaii, Western Australia), where interspecific competition is likely to be less intense. However the consistency of the geographic pattern also suggests that $P$. damicornis is unable to vary the relative importance of sexual and (intrinsic) asexual reproduction at a more local scale or over a short time frame. In contrast, local variation in the relative importance of asexual reproduction to recruitment has been reported for sea anemones, where populations on stable rock platforms are far less genetically diverse than those on adjacent unstable boulder shores (Ayre 1984) or spatially heterogenous mussel beds (Sebens 1982). For corals, competition may be lowest and asexual reproduction more favoured during expansion phases (e.g. following initial colonisation after a severe storm or episode of predation by Acanthaster planci). However, the reef crest sites from which we sampled varied 
in their level of crowding, and even though several had been damaged relatively recently (e.g. at Heron Island; Connell et al. 1997) we found no evidence of successful asexual reproduction by planulation or fragmentation at any location. Furthermore, Ayre \& Dufty (1994) and Benzie et al. (1995) did not detect variation in reproductive mode across a range of habitats for Seriatopora hystrix and $P$. damicornis, respectively.

\section{Geographic variation and gene flow}

Pocillopora damicornis shows little large-scale genetic variation on the GBR compared to other brooders. Our analyses revealed that for each of 6 apparently unlinked loci there was consistently little variation among groups of $P$. damicornis collected from locations (reefs) separated by up to $1200 \mathrm{~km}$ (mean $F_{\mathrm{Lr}}=0.008$ Table 3). This level of variation is similar to values reported for broadcast spawning taxa on the GBR (Benzie \& Stoddart 1992, Williams \& Benzie 1993, Benzie 1994, Burnett et al. 1994, Doherty et al. 1995) and in other spawning species from elsewhere (e.g. molluscs: Ward 1990, Murray-Jones \& Ayre 1997; and temperate cnidarians: Hunt \& Ayre 1989, McFadden et al. 1996). In comparison, much more spatial variation has typically been reported for viviparous (brooding) taxa. Examples include the brooding fish Acanthochromis polyacanthus $\left(F_{\mathrm{LT}}=0.79\right.$; Doherty et al. 1995$)$ and the zoanthid Zoanthus copperingeri on the GBR ( $F_{L T}=$ $0.039 \pm 0.004$; Burnett et al. 1995), the temperate coral Balanophyllia elegans $\left(F_{L T}=0.31\right.$; Hellberg 1994), the colonial ascidians Botrylloides magnicoecum and Stolonica australis $\left(F_{\mathrm{LT}}=0.2\right.$; Ayre et al. unpubl.).

The apparent disparity between the scale of dispersal of Pocillopora damicornis and other brooded species is likely to be attributable to physiological or behavioural properties of their larvae. For example most corals acquire their symbiotic zooxanthellae after settlement, but the brooded larvae of $P$. damicomis obtain theirs before release (Harrison \& Wallace 1990). Consequently, planulae of $P$. damicornis can potentially supplement diminishing supplies of yolk by photosynthesis during their plankton phase. Atoda's (1947) classic aquarium studies of the settlement of $P$. damicornis showed that $69 \%$ settled very quickly within $2 \mathrm{~d}$ of release, while the last $2 \%$ settled after 6 to $13 \mathrm{~d}$. More recently, Richmond (1987a, b) demonstrated that $3 \%$ of larvae of $P$. damicornis remained competent to settle after $103 \mathrm{~d}$ under laboratory conditions. In the present study, we detected most genetic variation at a local scale (within reefs). These results are consistent with previous studies of larval properties in $P$. damicornis; we conclude that planulae may often settle close to their parental colonies, but some proportion remain competent and planktonic for long periods and are widely dispersed if they are swept from the natal reef.

The levels of gene flow inferred here are relatively high in an evolutionary context, reflecting the low levels of differentiation between distant reefs. However, the model we applied [Wright's (1969) island model] assumes that gene flow is (1) bidirectional and (2) at a stable equilibrium. Neither assumption is realistic. Large-scale currents on the GBR flow predominantly southward (Williams et al. 1984) although they have a complex pattern close to individual reefs (Black et al. 1991). Furthermore, rates of settlement of larvae and subsequent recruitment into adult populations are notoriously variable (non-equilibrial) even over decadal time-scales (e.g. Connell 1973, Connell et al. 1997). Our estimate of gene flow along the GBR is similar to that for species with relatively long larval durations, including the starfish Acanthaster planci $\left(N_{\mathrm{e}} m=\right.$ 27 to 50; Benzie \& Soddart 1992), 3 species of clam Tridacna ( $N_{\mathrm{e}} m=20$ to infinity), and 2 species of fish, Pterocaesio chyrozona and Ctenochaetus striatus $\left(N_{\mathrm{e}} m=\right.$ 45 and 108; Doherty et al. 1995). In contrast, much smaller levels of gene flow among neighbouring reefs have been estimated for the pocilloporid coral Seriatopora hystrix $\left(N_{e} m=1.0\right.$; Ayre \& Dufty 1994) and the brooding fish Acanthochromis polyacanthus $\left(N_{\mathrm{e}} m=\right.$ 0.06; Doherty et al. 1995). Interestingly, Atoda (1951) also measured the larval behaviour of $S$, hystrix, and found that it settled substantially faster than Pocillopora damicornis. Specifically, 3 times as many $S$. hystrix settled with $24 \mathrm{~h}$ of release $(65 \%$ vs $19 \%$ for Pocillopora, $\mathrm{n}=208$ and 594, respectively). All the Seriatopora had settled after $4 \mathrm{~d}$, whereas the last $8 \%$ of the Pocillopora larvae settled from Day 5 to 13 (Atoda 1947, 1951).

Finally, our study of populations of Pocillopora damicornis on the GBR provides further evidence of the wide-spread geographic variation in life history reported for this species. In particular, our results and those of Benzie et al. (1994) are in clear contrast to comparable genetic studies from Western Australia and Hawaii (Stoddart 1984b, 1988), where asexual planulae accur. In Hawaii, 2 distinctive colour morphs of $P$. damicornis exhibit distinctive lunar cycles of planula release, and consequently they may be reproductively isolated (Richmond \& Jokiel 1984, Stoddart 1988). In the Eastern Pacific, P. damicornis may not planulate at all (Richmond 1985, 1987a), but instead it reproduces sexually as a broadcast spawner (Glynn et al. 1991) and asexually by frequent fragmentation (Richmond $1987 \mathrm{a}$ and references therein). Larval dispersal and gene flow appear to be sufficient to ensure relatively uniform expression of life-history characters along very large reefs systems (e.g. the GBR vs subtropical Western Australian reefs), but each of these 
systems is apparently evolutionarily independent and may indeed represent not just a different selective environment but a different gene pool or species.

Acknowledgements. This work was supported by ARC grants to T.P.H. and D.J.A., by James Cook University and the Australian Flora and Fauna Research Centre of the University of Wollongong. We thank Liz Dinsdale for excellent technical assistance, and B. Dinsdale, V. Hall, L. Smith, J. Tanner, C. Wallace, and J. Wolstenholme for further help in the field and lab. Comments by V. Hall, J. Tanner, B. Willis and several anonymous referees helped to improve the manuscript. This is contribution number 155 of the Ecology and Genetics Group of UW, and 155 of the Coral Ecology Group at JCU.

\section{LITERATURE CITED}

Atoda K (1947) The larva and postlarval development of some reef-building corals. I. Pocillopora damicornis cespitosa (Dana). Rep Tohoku Univ, 4th Ser (Biology), Vol XVIII, No. 1, p 24-47

Atoda $\mathrm{K}$ (1951) The larva and pastlarval development of some reef-building corals. V. Seriatopora hystrix Dana. Rep Tohoku Univ, 4 th Ser (Biology), Vol XIX, No. 1, p 33-39

Ayre DJ (1984) The effects of sexual and asexual reproduction on geographic variation in the sea anemone Actinia tenebrosa. Oecologia 62:222-229

Ayre DJ (1990) Population subdivision in Australian marine invertebrates: larval connections versus historical factors. Aust J Ecol 15:403-411

Ayre DJ, Dufty SL (1994) Restricted gene flow in the viviparous coral Seriatopora hystrix on Australia's Great Barrier Reef. Evolution 48:1183-1201

Ayre DJ, Reid J, Wishart J (1991) Genetic subdivision within the eastern Australian population of the sea anemone Actinia tenebrosa. Mar Biol 109:379-390

Ayre DJ, Resing JM (1986) Sexual and asexual production of planulae in reef corals. Mar Biol 90:187-190

Ayre DJ, Whelan RJ, Read M (1994) Unexpectedly high levels of selfing in the Australian shrub Grevillea barklyana (Proteaceae). Heredity 72:168-174

Ayre DJ, Willis BL (1988) Population structure in the coral Pavona cactus: clonal genotypes show little phenotypic plasticity. Mar Biol 99:495-505

Bell G (1982) The masterpiece of nature: the evolution and genetics of sexuality. University California Press, Berkeley

Bell G (1988) Uniformity and diversity in the evolution of sex. In: Michod RE, Levin BR (eds) The evolution of sex. Sinauer, Sunderland, MA, p 126-138

Benzie JAH (1994) Patterns of gene flow in the Great Barrier Reef and Coral Sea. In: Beaumont AR (ed) Genetics and evolution of aquatic organisms. Chapman and Hall, London, p $67-79$

Benzie JAH, Haskell A, Lehman H (1995) Variation in the genetic composition of coral (Pocillopora damicornis and Acropora palifera) populations from different reef habitats. Mar Biol 121:731-739

Benzie JAH, Stoddart JA (1992) Genetic structure of outbreaking and non-outbreaking crown-of-thorns starfish (Acanthaster planci) populations in Australia. Mar Biol 112:119-130

Billingham MJ, Ayre DJ (1996) Genetic subdivision in the subtidal, clonal sea anemone Anthothoe albocincta. Mar Biol 125:153-163
Black KP, Moran PJ, Hammond LS (1991) Numerical models show coral reefs can be self-seeding. Mar Ecol Prog Ser $74: 1-11$

Borsa P, Jousselin Y, Delay B (1992) Relationships between allozymic heterozygosity, body size and survival to natural anoxic stress in the palourde, Ruditapes decussatus L. (Bivalvia: Veneridae). J Exp Mar Biol Ecol 155:169-181

Burnett WJ, Benzie JAH, Beardmore JA, Ryland JS (1994) High genetic variability and patchiness in a common Great Barrier Reef zoanthid (Palythoa caesia). Mar Biol $121: 153-160$

Burnett WJ, Benzie JAH, Beardmore JA, Ryland JS (1995) Patterns of genetic subdivision in populations of a clonal cnidarian, Zoanthus coppingeri, from the Great Barrier Reef. Mar Biol 122:665-673

Burton RS (1986) Evolutionary consequences of restricted gene flow among natural populations of the copepod Tigriopus californicus. Bull Mar Sci 39(2):526-535

Carvalho GR (1994) Genetics of aquatic clonal organisms. In: Beaumont AR (ed) Genetics and evolution of aquatic organisms. Chapman and Hall, London, p 291-322

Connell JH (1973) Population ecology of reef building corals. In: Jones OG, Endean R (eds) Biology and geology of coral reefs, Vol 2. Academic Press, New York, p 205-245

Connell JH (1978) Diversity in tropical rain forests and coral reefs. Science 199:1302-1310

Connell JH, Hughes TP, Wallace CC (1997) A 30 year study of coral community dynamics: influence of disturbance and recruitment on abundance, at several scales in space and time. Ecol Monogr 67 (in press)

Crow JF, Kimura M (1970) An introduction to population genetics theory. Harper and Row, New York

Doherty PJ, Planes S, Mather P (1995) Gene flow and larval duration in seven species of fish from the Great Barrier Reef. Ecology 76:2373-2391

Done TJ (1982) Patterns in the distribution of coral communities across the central Great Barrier Reef. Coral Reefs 1 $95-107$

Duffy JE (1993) Genetic population structure in two tropical sponge-dwelling shrimps that differ in dispersal potential. Mar Biol 116:459-470

Dustan P (1979) Distribution of zooxanthellae and photosynthetic chloroplast pigments of the reef-building coral Montastrea annularis (Ellis and Solander) in relation to depth on a West Indian coral reef. Bull Mar Sci 29(1): $79-95$

Fitt WK, Spero JJ, Halas J, White MW, Porter JM (1993) Recovery of the coral Montastrea annularis in the Florida Keys after the 1987 Caribbean 'bleaching event' Coral Reefs 12:57-64

Foltz DW (1986) Null alleles as a possible cause of heterozygote deficiency in the oyster Crassostrea virginica. Biochem Genet 24:941-956

Foster AB (1979) Phenotypic plasticity in the reef corals Montastrea annularis (Ellis and Solander) and Sidastrea siderea (Ellis and Solander). J Exp Mar Biol Ecol 39:25-54

Glesener RR, Tilman D (1978) Sexuality and the components of environmental uncertainty: clues from geographic parthenogenesis in terrestrial animals. Am Nat 112: $659-673$

Glynn PW, Gassman NJ, Eakin CM, Cortes J, Smith DB, Guzman $\mathrm{HH}$ (1991) Reef coral reproduction in the eastern Pacific: Costa Rica, Panama, and Galapagos Islands (Ecuador). I. Pocilloporidae. Mar Biol 109:355-368

Grigg RW, Maragos JE (1974) Recolonization of hermatypic corals on submerged lava flows in Hawaii. Ecology 55: $387-395$ 
Hall V, Hughes TP (1994) Reproductive strategies of modular organisms: comparative studies of reef building corals. Ecology 77:950-963

Harris $H_{1}$ Hopkinson DA (1976) Handbook of electrophoresıs in human genetics. North-Holland, Amsterdam

Harrison PL, Wallace CC (1990) Reproduction, dispersal and recruitment of Scleractinian corals. In: Dubinsky $Z$ (ed) Ecosystems of the world 25: coral reefs. Elsevier, New York, p 133-207

Hebert PDN, Ward RD, Weidler LJ (1988) Clonal-diversity patterns and breeding system variation in Daphnia pulex, an asexual-sexual complex. Evolution 42:147-159

Hedgecock D (1986) Is gene flow from pelagic larval dispersal important in the adaptation and evolution of marine invertebrates? Bull Mar Sci 39:550-564

Hedrick PW, Jain S, Holden L (1978) Multilocus systems in evolution. Evol Biol 11:101-184

Highsmith RC (1982) Reproduction by fragmentation in corals. Mar Ecol Prog Ser 7:207-226

Hill WG (1975) Estimation of linkage disequilibrium in randomly mating populations. Heredity 33:229-239

Hochberg Y (1988) A sharper Bonferroni procedure for multtple tests of significance. Biometrika 75:800-802

Hoffmann RJ (1986) Variation in the contributions of asexual reproduction to the genetic structure of populations of the sea anemone Metridium senile. Evolution 40:357-365

Holtsford TP, Ellstrand NC (1992) Genetic and environmental variation in the floral traits affecting outcrossing rate in Clarkia tembloriensis (Onagraceae). Evolution 46 $216-225$

Hughes TP, Ayre DJ, Connell JH (1992) The evolutionary ecology of corals. Trends Ecol Evol 9:292-298

Hunt A (1993) Effects of contrasting patterns of larval dispersal on the genetic connectedness of local populations of two intertidal starfish: Patiriella calcar and $P$. exigua. Mar Ecol Prog Ser 92:179-186

Hunt A, Ayre DJ (1989) Population structure in the sexually reproducing sea anemone Oulactis muscosa. Mar Biol 102 $537-544$

Innes D, Hebert DPN (1988) The origin and genetic basis of obligate parthenogenesis in Daphnia pulex. Evolution 4.2: $1024-1035$

Johnson MS, Black R (1984) The Wahlund effect and the geographical scale of variation in the intertidal limpet, Siphonaria sp. Mar Biol 79:295-302

Karlson RH, Hughes TP, Karlson SR (1996) Density-dependent dynamics of soft coral aggregations: the significance of clonal growth and form. Ecology 77(5):1592-1599

Knowlton N, Jackson JBC (1993) Inbreeding and outbreeding in marine invertebrates. In: Thornhill NW (ed) The natural history of inbreeding and outbreeding: theoretical and empirical perspectives. University of Chicago Press. Chicago, p 200-249

Knowlton N, Jackson JBC (1994) New taxonomy and niche partitioning on coral reefs: jack of all trades or master of some? Trends Ecol Evol 9:7-9

Knowlton N. Weil E, Weigt LE, Guzman HM (1992) Sibling species in Montastrea annularis, coral bleaching, and the coral climate record. Science 255:330-333

Lessios H (1992) Testing electrophoretic data for agreement with Hardy-Weinberg expectations. Mar Biol 112:517-523

MacKay TFC, Doyle RW (1978) An ecological genetic analysis of the settling behavior of a marine polychaete. Heredity 40:1-12

Maynard Smith J (1978) The evolution of sex. Cambridge University Press, Cambridge

McFadden CS, Grosberg RK, Cameron BB, Karlton DP, Sec- ord DA (1996) Genetic relationships within and between solitary and clonal forms of the sea anemone Anthopleura elegantissima revisited: evidence for the existence of two speries. Mar Biol 128:127-1.39

Murray-Jones S, Ayre DJ (1997) High levels of gene flow in the surf bivalve Donax deltoides (B1valvia: Donacidae) on the east coast of Australla. Mar Biol 128:83-89

Nelson VM (1994) Demographic processes and spatial heterogenity in community structure and dynamics of corals on the reef crest. PhD thesis, James Cook University of North Queensland, Townsville

Richardson BJ, Baverstock PR, Adams M (1986) Allozyme electrophoresis: a handbook for animal systematics and population studies. Academic Press, Sydney

Richmond R (1985) Variation in the population biology of Pocillopora damicornis across the Pacific Ocean. Proc $5 \mathrm{th}$ Int Coral Reef Congr 6:101-106

Richmond R (1987a) Energetic relationships and biogeographical differences among fecundity, growth and reproduction in the reef coral Pocillopora damicornis. Bull Mar SCI 42(2):594-604

Richmond R (1987b) Energetics, competency, and long-distance dispersal of planula larvae of the coral Pocillopora damicornis. Mar Biol 93:527--533

Richmond RH, Jokiel PL (1984) Lunar periodicity in larva release in the reef coral Pocillopora damicornis at Enewatak and Hawaii. Bull Mar Sci 34:280-287

Rosen BR (1981) The tropical high diversity enigma: the corals eye view. In: Florey PL (ed) Chance, change and challenge. The evolving biosphere. British Museum (Natural History) and Cambridge University Press, Cambridge, p 103-129

Sebens KP (1982) Recruitment and habitat selection in the intertidal sea anemones Anthopleura elegantissima. J Exp Mar Biol Ecol 59:103-124

Selander RK, Smith MH, Yank SY, Johnston WE, Gentry JB (1971) Biochemical polymorphism and systematics in the genus Peromyscus. I. Variation in the old-field mouse (Peromyscus polionotus\}. Stud Genet 6:49-90

Stearns $S$ (1989) The evolutionary significance of phenotypic plasticity. BioSci 39:436-445

Stobbart B, Benzie JAH (1994) Allozyme electrophoresis demonstrates that the scleractinian coral Montipora digitata is two species. Mar Biol 118:183-190

Stoddart JA (1983) Asexual production of planulae in the coral Pocillopora damicornis. Mar Biol 76:279-284

Stoddart JA (1984a) Genetic structure within populations of the coral Pocillopora damicornis. Mar Biol 81:19-30

Stoddart JA (1984b) Genetic differentiation amongst populations of the coral Pocillopora damicornis off southwestern Australia. Coral Reefs 3:149-156

Stoddart JA (1988) Coral populations fringing islands: larval connections. Aust J Mar Freshwat Res 39:109-115

Stoddart JA, Black R (1985) Cycles of gametogenesis and planulation in the coral Pocillopora damicornis. Mar Ecol Prog Ser 23:153-164

Stoddart JA, Taylor JF (1988) Genotypic diversity: estimation and prediction in samples. Genetics 118:705-711

Szmant AM, Weil E, Miller MW, Colón DE (1997) Hybridization within the species complex of the scleractinian coral Montastrea annularis (Ellis and Solander 1786). Mar Biol (in press)

Thorson G (1950) Reproduction and larval ecology of marine bottom invertebrates. Biol Rev 25:1-45

Toonen RJ (1993) Environmental and heritable components of settlement behavior of Hydroides dianthus (Serpulidae: Polychaeta). MSc thesis, University of North Carolina at Wilmington 
Van Veghel MLJ (1994) Reproductive characteristics of the polymorphic Caribbean reef building coral Montastrea annularis. I. Gametogenesis and spawning behavior. Mar Ecol Prog Ser 109:209-219

Van Veghel MLJ, Bak RPM (1993) Intraspecific variation of a dominant Caribbean reef building coral, Montastrea annularis: genetic, behavioral and morphometric aspects. Mar Ecol Prog Ser 92:255-265

Veron JEN (1986) Corals of Australia and the Indo-Pacific Angus and Robertson, Sydney

Veron JEN, Pichon M (1976) Scleractinia of eastern Australia Part I. Families Thamnasteriidae, Astroceniidae, Pocilloporidae. Monogr Ser Aust Inst Mar Sci 1:1-86

Wallace B (1981) Basic population genetics. Columbia University Press, New York

Ward R (1990) Biochemical genetic variation in the genus Littorina (Prosobranchia: Mollusca). Hydrobiologia 193: $53-69$

Ward S (1992) Evidence for broadcast spawning as well as brooding in the scleractinian coral Pocillopora damicornis. Mar Biol 112(4):641-646

Weil E, Knowlton N (1994) A multi-character analysis of the Caribbean coral Montastrea annularis (Ellis and Solander, 1786 ) and its two sibling species, $M$. faveolata (Ellis and Solander, 1786) and $M$. franksi (Gregorgy, 1895). Bull Mar Sci 55(1):151-175

Weir BS (1990) Genetic data analysis. Sinauer, Sunderland, MA

Weir BS, Cockerham CC (1984) Estimating F-statistics for the analysis of population structure. Evolution 41:1358-1370

Editorial responsibility: Ronald Karlson (Contributing Editor), Newark, Delaware, USA
Williams DMcB, Wolanski E, Andrews JC (1984) Transport mechanisms and the potential movement of larvae in the central region of the Great Barrier Reef. Coral Reefs 3: $229-236$

Williams GC (1975) Sex and evolution. Princeton University Press, Princeton, NJ

Williams ST, Benzie JAH (1993) Genetic consequences of long larval life in the starfish Linckia laevigata (Echinodermata: Asteroidea) on the Great Barrier Reet. Mar Biol $117: 71-77$

Willis BL (1985) Phenotypic plasticity versus phenotypic stability in the reef corals Turbinaria mesenterina and Pavona cactus. Proc 5th Int Coral Reef Congr 4:107-112

Willis BL, Ayre DJ (1985) Asexual reproduction and genetic determination of growth form in the coral Pavona cactus: biochemical genetic and immunogenetic evidence. Oecologia 65:516-525

Willis BL, Babcock RC. Harrison PL, Wallace CC (1997) Experimental hybridization and breeding incompatibilities within the mating systems of mass spawning reef corals. Coral Reefs 16 (in press)

Wilson CC, Hebert PDN (1992) The maintenance of taxon diversity in an asexual assemblage: an experimental analysis. Ecology 73:1462-1472

Wright S (1969) Evolution and genetics of natural populations 2. The theory of gene frequencies. Univ Chicago Press, Chicago

Wright S (1978) Evolution and genetics of natural populations 4. Variability within and among natural populations. Univ Chicago Press, Chicago

Submitted: November 11, 1996; Accepted: September 23, 1997 Proofs received from author(s): November 12, 1997 